\title{
Cell death, clearance and immunity in the skeletal muscle
}

\author{
C Sciorati ${ }^{1}$, E Rigamonti ${ }^{1}$, AA Manfredi ${ }^{1,2}$ and P Rovere-Querini ${ }^{\star, 1,2}$
}

The skeletal muscle is an immunologically unique tissue. Leukocytes, virtually absent in physiological conditions, are quickly recruited into the tissue upon injury and persist during regeneration. Apoptosis, necrosis and autophagy coexist in the injured/ regenerating muscles, including those of patients with neuromuscular disorders, such as inflammatory myopathies, dystrophies, metabolic and mitochondrial myopathies and drug-induced myopathies. Macrophages are able to alter their function in response to microenvironment conditions and as a consequence coordinate changes within the tissue from the early injury throughout regeneration and eventual healing, and regulate the activation and the function of stem cells. Early after injury, classically activated macrophages ('M1') dominate the picture. Alternatively activated M2 macrophages predominate during resolution phases and regulate the termination of the inflammatory responses. The dynamic M1/M2 transition is increasingly felt to be the key to the homeostasis of the muscle. Recognition and clearance of debris originating from damaged myofibers and from dying stem/ progenitor cells, stromal cells and leukocytes are fundamental actions of macrophages. Clearance of apoptotic cells and M1/M2 transition are causally connected and represent limiting steps for muscle healing. The accumulation of apoptotic cells, which reflects their defective clearance, has been demonstrated in various tissues to prompt autoimmunity against intracellular autoantigens. In the muscle, in the presence of type I interferon, apoptotic myoblasts indeed cause the production of autoantibodies, lymphocyte infiltration and continuous cycles of muscle injury and regeneration, mimicking human inflammatory myopathies. The clearance of apoptotic cells thus modulates the homeostatic response of the skeletal muscle to injury. Conversely, defects in the process may have deleterious local effects, guiding maladaptive tissue remodeling with collagen and fat accumulation and promoting autoimmunity itself. There is strong promise for novel treatments based on new knowledge of cell death, clearance and immunity in the muscle.

Cell Death and Differentiation (2016) 23, 927-937; doi:10.1038/cdd.2015.171; published online 12 February 2016

Facts

- M1/M2 timely transition triggered by the recognition of apoptotic cells in the skeletal muscle is a key to tissue homeostasis.

- Regulatory T lymphocytes accumulate in the injured skeletal muscle and are instrumental for healing, whereas conventional $\mathrm{CD}^{+}$or $\mathrm{CD}^{+} \mathrm{T}$ lymphocytes are found in persistently inflamed muscles.

- Defective clearance of dead cells prompts maladaptive muscle remodeling with deposition of collagen and fat.

- The generation of apoptotic cell-derived autoantigens induces autoimmunity and self-maintaining immunemediated tissue damage in the presence of type 1 interferon.

\section{Open Questions}

Which are the phagocytic receptors and bridging molecules involved in the recognition of apoptotic cells in the muscle and how do they influence the outcome of the clearance?

- Do regulatory T cells control immune cell function in muscle and physiologically restrict autoimmunity in the tissue?

- Would it be possible to revert the noxious effects of maladaptive tissue remodeling and of autoimmunity by prompting debris disposal?

\section{Unique Immune Privileges of the Skeletal Muscle}

Immune privilege is an evolutionary conserved adaptation that protects vulnerable tissues from the noxious effects of inflammation. Allogeneic transplanted tissues are not rejected

\footnotetext{
${ }^{1}$ Division of Immunology, Transplantation and Infectious Disease, San Raffaele Scientific Institute and Vita-Salute San Raffaele University, Milano, Italy and ${ }^{2}$ Unit of Medicine and Clinical Immunology, San Raffaele Scientific Institute, Milano, Italy

*Corresponding author: P Rovere-Querini, Division of Immunology, Transplantation and Infectious Disease, DIBIT 2A1, Ospedale San Raffaele, via Olgettina 58, Milano 20132, Italy. Tel: +39 02 26436768; Fax: +39 02 26435283; E-mail: rovere.patrizia@ @sr.it

Abbreviations: MCH, Major histocompatibility complex; APCs, antigen presenting cells; CK, creatine phosphokinase; ROS, reactive oxygen species; DAMPs, damage Associated Molecular Patterns; HMGB1, high-mobility group box 1; TLR, Toll-like receptor; TUNEL, terminal deoxynucleotidyl transferase dUTP nick end labelling; NETs, neutrophil extracellular traps; FAP, fibroadipogenic precursors; MKP-1, MAP kinase phosphatase-1; AMPK, AMP-activated protein kinase; CREB, cAMP response element-binding protein; PS, phospatidylserine; IIM, inflammatory myopathies; HisRS, histidyl t-RNA synthase

Received 30.10.15; revised 14.12.15; accepted 16.12.15; Edited by G Kroemer; published online 12.2.16
} 


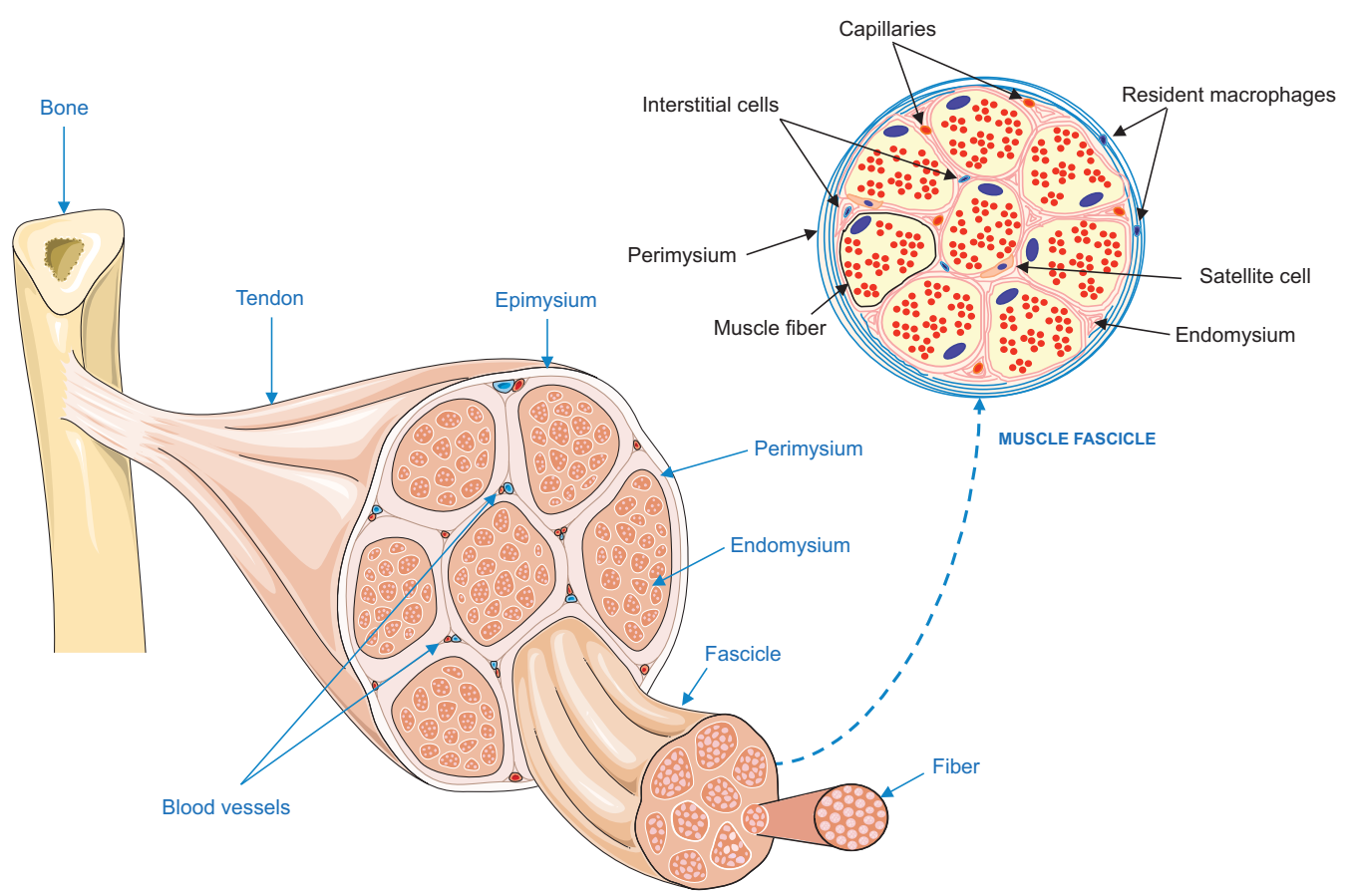

Figure 1 Physiology of skeletal muscle. Skeletal muscles as organs consist of muscle fibers bound by connective tissue. Skeletal muscles are attached to bone by tendons composed of connective tissue. Each muscle is wrapped in a sheath of connective tissue called the epimysium that allows a muscle to contract and move while maintaining its structural integrity. Bundles of muscle fibers, called fascicles, are covered by the perimysium. Inside each fascicle, each muscle fiber is encased in a thin connective tissue layer called the endomysium that contains the extracellular fluid and nutrients to support the muscle fiber. Nutrients are supplied via blood vessels to the muscle tissue. In close proximity to the muscle fibers are the satellite cells that are the main source of myogenic precursors. A large number of cells are present in the interstitial spaces of skeletal muscle and together with satellite cells they sustain the life-long maintenance of muscle tissue

when transplanted in privileged sites, or immunological 'sanctuaries', that are often crucial for the survival either of the individual (the eye and the brain) or of the species (gonads, the pregnant uterus). ${ }^{1,2}$ The immune privilege could provide an evolutionary advantage, making immune responses less likely to cause irreversible damage in sites in which cells cannot be easily replaced. ${ }^{3}$ The immune privilege involves systemic and local regulatory events. They include the physical separation from the immune system by anatomical or functional barriers, such as the blood-brain or the blood-retina barriers, ${ }^{4}$ a limited constitutive expression of major histocompatibility complex (MHC) molecules, the absence of resident professional antigen-presenting cells (APCs) and a scant lymphatic drainage. When barriers are disrupted, immune-privileged sites initiate regulatory processes that: (1) limit the extent of immune activation and (2) select the potentially less damaging immune response. This has been well characterized in particular for the ocular immune privilege ${ }^{5}$ but plays a role in the homeostasis of other immunologic sanctuaries, including the brain. ${ }^{6}$

The skeletal muscle is the largest cellular compartment of the body, characterized in physiological conditions by a relatively slow turnover. It is an immunologically unique tissue or a 'nonclassical' immunological privileged site. It is not endowed with anatomical barriers and the lymphatic vasculature is well represented. However, immune cells, including APCs, are in physiological conditions virtually absent and the tissue expression of MHC class I or class II molecules is limited (Figure 1). Moreover, the outcome of sterile inflammation in the skeletal muscle appears to be the recruitment of alternatively activated macrophages and of regulatory $T$ cells that play non-redundant roles in muscle regeneration and possibly contribute to limit autoimmunity ${ }^{7,8}$ (see below). Thus, muscle inflammation comprises signals that possibly contribute to initiate tissue regeneration and to terminate it in a timely manner once the tissue has healed and its homeostatic function is no longer required. Data in recent years indicate that the recognition and the clearance of cells dying in the skeletal muscle are critical for muscle homeostasis and maintenance of tolerance. This paradigm, even if exquisitely unique of muscle immunobiology, could be important to understand the link between inflammation and tissue repair at other anatomical sites.

\section{The Prey: Cell Death in the Skeletal Muscle}

DNA fragmentation, caspase activation and mitochondria apoptosis-associated protein release have all been described in the muscle as a consequence of trauma, hindlimb unloading, disuse, genetic defect including dystrophy or age-associated sarcopenia. ${ }^{9-12}$ The stereotyped sequence of events that characterize apoptosis of single cells can hardly account for the complexity of the programmed death of multinucleated myofibers. Programmed death causes the selective removal of individual targeted myonuclei and of 'myonuclear domains', the limited areas of cytoplasm that 
individual myonuclei support. ${ }^{13,14}$ Muscle fiber segment with TUNEL (terminal deoxynucleotidyl transferase dUTP nick end labeling)-positive nuclei alongside intact nuclei has been described. ${ }^{15}$ Myonuclear apoptosis might contribute to skeletal muscle atrophy (however, see Bruusgaard et al. ${ }^{16}$ ). Apoptosis in response to acute muscle injury appears more straightforward and is modulated by metabolic pathways involving ganglioside biosynthesis. ${ }^{17}$

Myofibers also dispose of damaged organelles by autophagy that is activated during muscle atrophy and variably contributes to the loss of muscle mass. ${ }^{18,19}$ The apoptotic process in the skeletal muscle might be preferentially activated to face defective autophagy, ${ }^{20}$ suggesting that the two processes are intermingled. Both apoptosis and autophagy possibly contribute to age-related sarcopenia that is associated with loss in the overall mass and with a reduced number of myofibers. ${ }^{14,21-25}$

Disorganization of myofibrils with $Z$ line loss, mitochondrial swelling and sarcolemmal disruption are hallmarks of the skeletal muscle necrosis. Intracellular moieties including myoglobin, creatine phosphokinase (CK) and other sarcoplasm proteins are released into the bloodstream. ${ }^{26}$ During intense exercise, on-going cell death and DNA fragmentation together with undamaged sarcolemma and preserved contractile proteins are detectable in the muscle. ${ }^{27,28}$ Necrosis-released enzymes are found in human blood after eccentric muscular contractions as those performed during marathon, weight-bearing exercises and downhill running. ${ }^{29,30}$ Serum CK might not only reflect fiber disruption. In highly energy-demanding conditions, fibers might prevent the bioenergetic collapse by the expulsion of ATP-consuming enzymes. CK would be redistributed to membrane blebs whereas bleb extrusion would allow expulsion of the enzyme. ${ }^{31}$

Acute sterile injury of the skeletal muscle results in the early mitochondrial generation of reactive oxygen species (ROS). These organelles undergo rapid disruption at later time points and non-mitochondrial sources of ROS generation emerge. In parallel, an antioxidant response is activated in both regenerating fibers and leukocytes that express high levels of free thiols and antioxidant enzymes. ${ }^{32}$ Intracellular damage-associated molecular patterns (DAMPs) are also released after injury, and their inflammatory action in the extracellular environment might contribute to recruit inflammatory phagocytes, to activate them and to prompt the immunogenicity of dying cells. ${ }^{33}$ The prototypical DAMP, high-mobility group box 1 (HMGB1), is a redox-sensitive moiety that in a predominantly reduced environment preferentially promotes leukocyte recruitment, upon formation of heterocomplexes with the chemokine (C-X-C motif) ligand 12 chemokine. The partially oxidized isoform in contrast preferentially activates the Toll-like receptor-4 (TLR4) with downstream chemokine and cytokine release. ${ }^{34-36}$ The terminally oxidized sulfonate isoform appears even less able to attract leukocytes or to elicit cytokines, even if it maintains the ability to modulate neutrophil integrin transactivation and degranulation. ${ }^{37}$

HMGB1 is weakly expressed in healthy muscles. ${ }^{32}$ The expression increases during regeneration in parallel with the antioxidant response in both fibers and leukocytes. A reduced environment may be important to maintain HMGB1 bioactivity. Indeed, oxidation abrogates both muscle stem cell migration in response to HMGB1 and their ability to differentiate into myofibers in vitro. ${ }^{25,32,38,39}$ The early antioxidant response in regenerating muscle might limit HMGB1 oxidation, thus allowing the timely recruitment of leukocytes, the activation of muscle stem cells, the reconstitution of the vasculature and the eventual successful muscle regeneration. ${ }^{25,39}$ Of importance, HMGB1 expression is modulated upon persistent immune-mediated damage of the muscle during inflammatory myopathies, suggesting that its generation might contribute to the natural history of these conditions. ${ }^{40,41}$

Apoptosis, necrosis and autophagy represent extremes of the response of the muscle to injury and often coexist (Figure 2). They have been extensively studied in animals exploiting various experimental models of damage. Most models recapitulate the sequence of injury/inflammation/ regeneration, even if they are characterized by different patterns of tissue remodeling, kinetics of repair and leukocytes preferentially involved. Table 1 summarizes the most widely used injury models.

Cell death has also been extensively studied in patient specimens and in experimental models of neuromuscular disorders, including inflammatory myopathies, metabolic and mitochondrial myopathies, dystrophinopathies and druginduced myopathies. ${ }^{42,43}$ Muscle dystrophies are paradigmatic examples of muscle fiber loss by necrosis, ${ }^{44}$ even if segmental apoptosis occurs with areas of caspase expression and TUNEL positivity adjacent to necrotic zones. ${ }^{45}$ Apoptosis has been described in inflammatory myopathies, ${ }^{46,47}$ at least in some cases as a result of the cytotoxic action of $\mathrm{T}$ lymphocytes. Finally, the generation of neutrophil extracellular traps (NETs), an event strictly associated with the activation of autophagy pathway in inflammatory leukocytes ${ }^{48}$ and modulated by the recognition of apoptotic cells, ${ }^{49}$ has been described in the muscle upon ischemia-reperfusion injury. ${ }^{50}$ Further studies will evaluate the relevance of NET contribution to muscle remodeling during autoimmune diseases and in homeostatic conditions.

Besides myonuclear apoptosis and myofiber necrosis, other cells die in the midst of the inflamed skeletal muscle (Figure 2). This is specifically the case of muscle stem cells and of stromal cells including fibroadipogenic progenitors (FAPs). Skeletal muscle injury is known to be associated with the early proliferation of the best-characterized muscle stem cells, the satellite cells. A fraction of proliferating satellite cells die, as assessed by positivity of the TUNEL assay and by the cleavage of poly ADP ribose polymerase, via a pathway involving the Foxo3 transcription factor. ${ }^{51}$ Specific pathways have apparently been generated to modulate the ability of satellite cells to survive in response to various environmental stimuli including those related to the angiopoietin $1 /$ Tie2 system, ${ }^{52}$ to the member of the Melanomaassociated antigen D1 family of proteins, necdin, ${ }^{53}$ and to the thyroid hormone. ${ }^{51}$ FAPs comprise multipotent mesenchymal progenitor cells ${ }^{54}$ that are a source of matrix-secreting activated myofibroblasts in the skeletal muscle. ${ }^{55}$ Their fate appears to be finely regulated by the extent and by the characteristics of the inflammatory response (see below) and their regulated death and clearance is possibly critical to 
prevent tissue fibrosis. Defective FAP clearance reflects and contributes to the maladaptive remodeling of the skeletal muscle. ${ }^{56}$

Inflammatory leukocytes represent another source of dying cells in the damaged/regenerating skeletal muscle. Their fate has not been characterized in detail. The kinetics of their accumulation in the tissue and the insight derived from the studies of apoptosis in other inflamed tissues strongly imply that regulated death and phagocytic clearance of infiltrated leukocytes are a prerequisite for appropriate resolution of the inflammatory response and possibly for repair of the injured tissue. ${ }^{57}$
Cell death
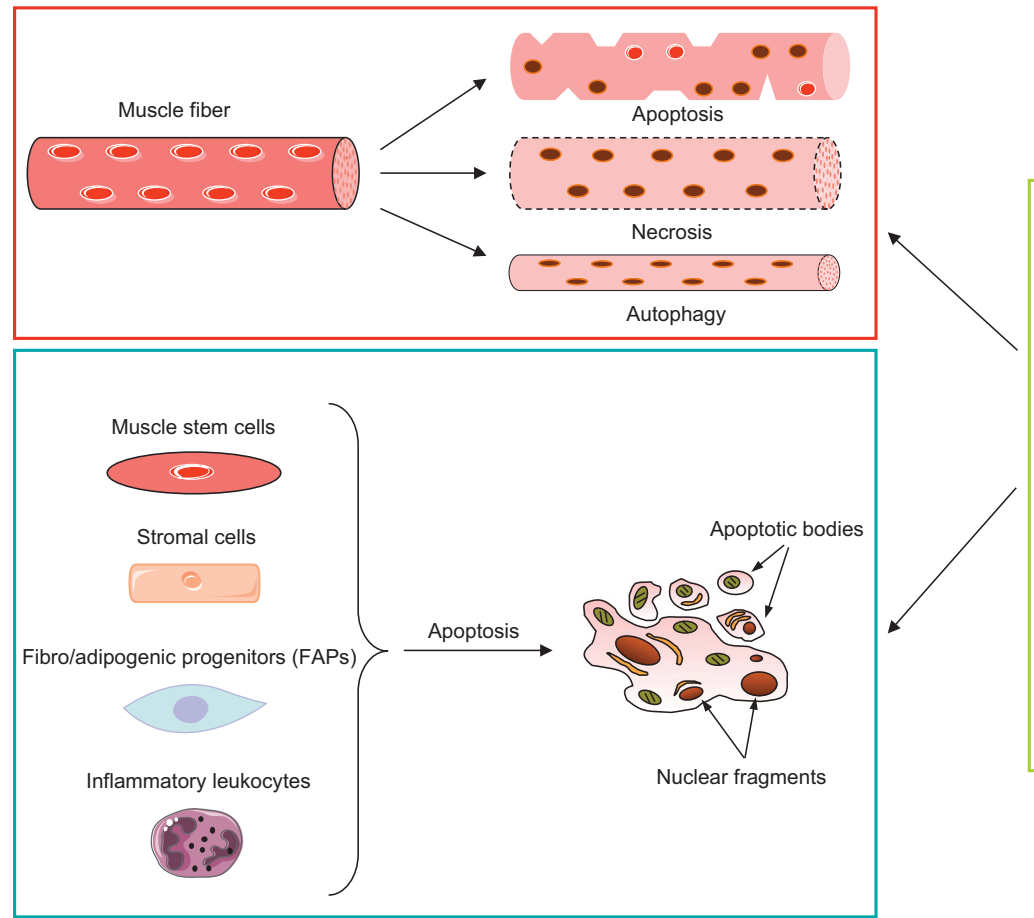

Debris clearance

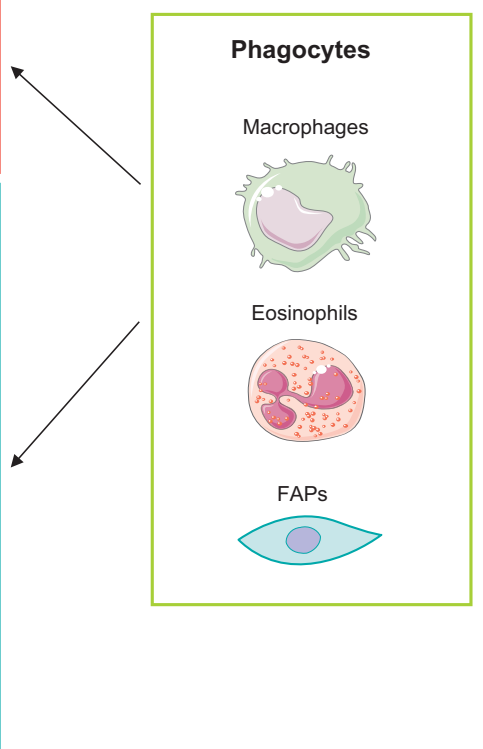

Figure 2 Cell death and phagocytic clearance in skeletal muscle. Muscle fibers die through apoptosis, necrosis and autophagy. Skeletal muscle death has been described in paraphysiological conditions and is a hallmark of several muscle diseases. Besides muscle fibers, other cells die after injury. A fraction of proliferating muscle stem cells as well as stromal cells and FAPs undergo apoptosis after muscle healing. Another source of dying cells is the inflammatory leukocytes that infiltrate the muscle after injury. Leukocytes, especially macrophages, are also responsible for the clearance of apoptotic cells, indispensable for the resolution of inflammation and tissue repair. FAPs also contribute to the phagocytosis of cellular debris

Table 1 Features of commonly employed experimental models of acute muscle damage

\begin{tabular}{|c|c|c|c|c|}
\hline Injury & Model & Muscles & Main characteristics & Reference \\
\hline \multirow[t]{6}{*}{ Mechanic } & Laceration & Soleus, gastrocnemius & $\begin{array}{l}\text { Severe fiber breakdown innervation involvement, inflammation, } \\
\text { slow regeneration, scar formation and incomplete recovery may } \\
\text { occur }\end{array}$ & 134,135 \\
\hline & Crush & $\begin{array}{l}\text { Gastrocnemius, tibialis } \\
\text { anterior, soleus }\end{array}$ & $\begin{array}{l}\text { Fiber blunt followed by necrosis, edema-induced spacing, } \\
\text { hemorrhage and inflammation, exercise-facilitated regenera- } \\
\text { tion, extracellular matrix deposition }\end{array}$ & $136-139$ \\
\hline & $\begin{array}{l}\text { Strain (electric stimulation, } \\
\text { traction, forced exercise) }\end{array}$ & $\begin{array}{l}\text { Gastrocnemius, quad- } \\
\text { riceps, hamstring, } \\
\text { soleus }\end{array}$ & $\begin{array}{l}\text { Fiber tears and sarcolemma breakdown, hemorrhage, tendon } \\
\text { involvement, extracellular matrix deposition, inflammation }\end{array}$ & $140-143$ \\
\hline & Freezing & $\begin{array}{l}\text { Gastrocnemius tibialis } \\
\text { anterior }\end{array}$ & Edema, inflammation, fast regeneration & 144,145 \\
\hline & Ischemia/reperfusion & Leg muscles & Inflammation, hemorrhage, slow regeneration & 146,147 \\
\hline & $\begin{array}{l}\text { Atrophy (limb suspension, } \\
\text { denervation or spinal cord } \\
\text { injury, antigravity) }\end{array}$ & $\begin{array}{l}\text { Leg muscles, } \\
\text { gastrocnemious }\end{array}$ & $\begin{array}{l}\text { Muscle mass loss, fiber size reduction, shift in fiber type, nuclei } \\
\text { loss, autophagy }\end{array}$ & $148-150$ \\
\hline \multirow[t]{2}{*}{ Chemical } & Toxin injection & $\begin{array}{l}\text { Tibialis anterior, quad- } \\
\text { riceps gastrocne- } \\
\text { mious, soleus }\end{array}$ & $\begin{array}{l}\text { Sarcolemma degradation with intact basal lamina, calcium } \\
\text { overload, inflammation }\end{array}$ & 26,151 \\
\hline & Glycerol injection & Tibialis anterior & $\begin{array}{l}\text { Necrosis of muscle fibers, vacuolar changes, inflammation, } \\
\text { adipose tissue infiltration }\end{array}$ & 152,153 \\
\hline
\end{tabular}




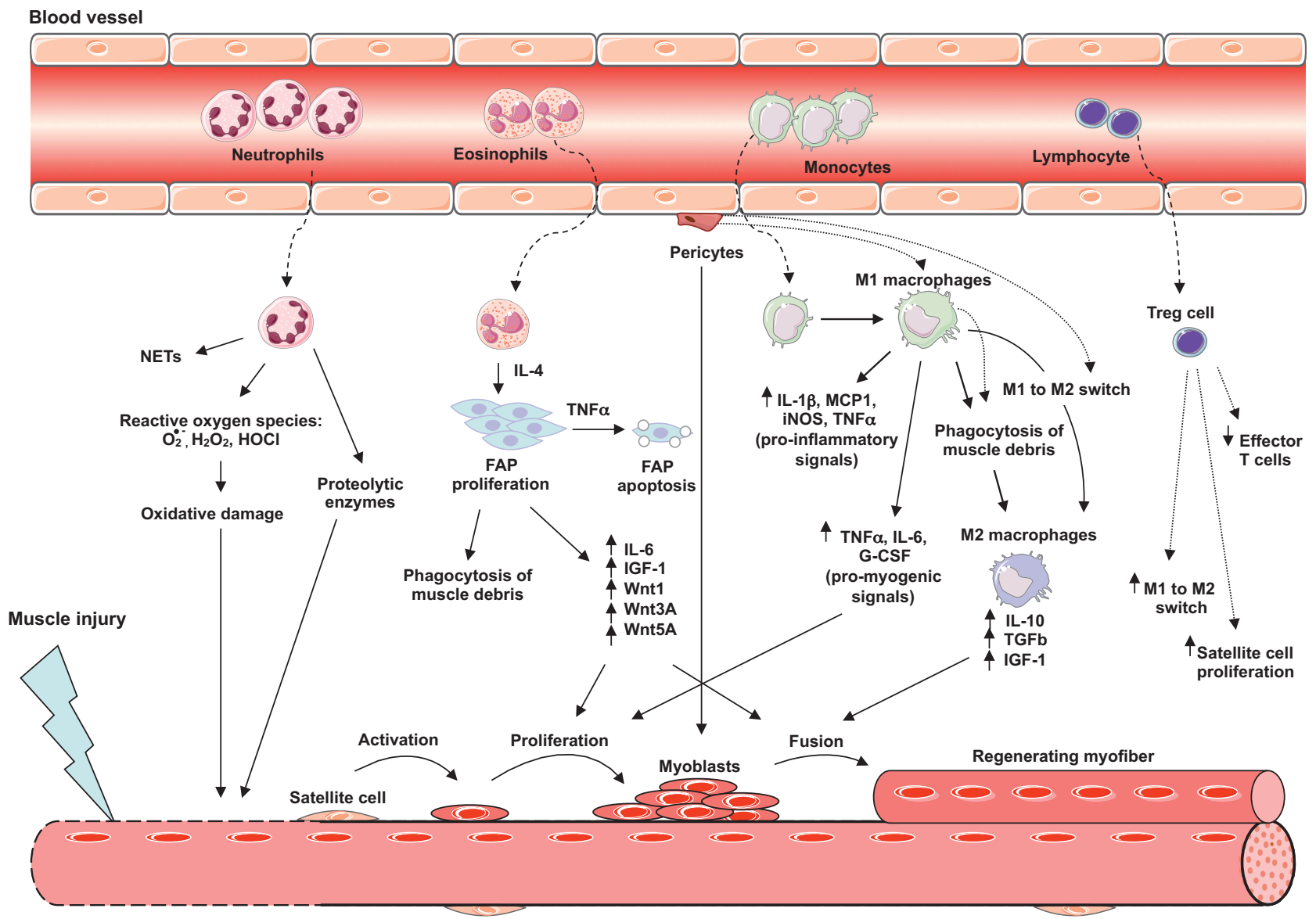

Muscle fiber

Figure 3 Skeletal muscle healing depends on inflammation. Efficient skeletal muscle healing occurs in overlapping phases of inflammation, proliferation and remodeling. Upon muscle injury, satellite cells activate, start proliferating and subsequently fuse and differentiate into new myotubes that later grow and replace damaged muscle. Several cell types modulate both proliferation and differentiation of satellite cells, in particular inflammatory cells that are recruited from the blood. Neutrophils and eosinophils firstly arrive in the damaged tissue. Neutrophils release ROS and proteolytic enzymes that further amplify the damage and local inflammation. Eosinophils induce the proliferation of FAPs that in turn contribute to debris clearance and satellite cell proliferation. Shortly after, monocytes extravasate in the injured areas where they differentiate in proinflammatory M1 macrophages that clear cellular debris and stimulate satellite cell proliferation. This initial Th1-driven inflammation is later overcome by an anti- inflammatory response that coincides with a M1-to-M2 switch. M2 macrophages and Th2 cytokines (IL-10, IGF-1, TGF $\beta$ ) reduce local inflammation and contribute to myoblast fusion and new myofiber formation. A variety of intrinsic and extrinsic factors are responsible for macrophage phenotypic polarization; pericytes and Treg cells represent an additional layer of control. Pericytes sustain the ability of macrophages to clear apoptotic cells and promote the expression of genes associated with their alternative activation. Treg cells begin to accumulate in damaged muscle within days after injury and contribute to muscle healing at several levels. They promote M1-to-M2 switch, increase satellite cell proliferation and modulate effector T cell (CD8+ or B cells)

\section{The Regeneration of Injured Muscles Depends on Inflammation}

Skeletal muscle has a remarkable capability to regenerate. Main players are the satellite cells, localized between the basal lamina and the fiber membrane. ${ }^{58}$ Satellite cells leave the quiescent state, characterized by expression of the paired-box protein $\operatorname{Pax} 7,{ }^{59}$ and proliferate, eventually yielding myoblasts that express the MyoD regulatory factor. ${ }^{60}$ After multiple cell divisions, myoblasts terminally differentiate and fuse, forming small centronucleated fibers that gradually grow in size providing complete muscle regeneration. ${ }^{60-63}$

Leukocytes are quickly drawn into the damaged muscle. An epimysial/perimysial connective tissue-resident macrophage population possibly endowed with antigen-presenting capacity and with the ability to migrate into the draining lymph would be in charge of the early attraction and local activation of inflammatory cells. ${ }^{64}$ Other sentinels of tissue injury, including platelets and mast cells, ${ }^{65}$ are likely to contribute. Leukocytes are constantly detectable in the injured muscle while the regeneration process occurs. They disappear once the tissue is completely healed. ${ }^{66}$ Polymorphonuclear cells, including neutrophils and eosinophils, are the first leukocytes to be recruited in the damaged tissue. Shortly after, macrophages accumulate and subsequently become the dominant leukocyte population. ${ }^{67,68}$ Macrophages are responsible for the removal of cellular debris, most likely including those derived from dying eosinophils and neutrophils (see above). Their ability to perceive the characteristics of the tissues that dramatically change from the early injury throughout regeneration and eventual healing and to coordinate the activation and the function of stem cells is critical for muscle 
homeostasis $^{69-71}$ (see below). Lymphocytes also accumulate in the injured skeletal muscle. In normal conditions they mostly comprise regulatory $\mathrm{T}$ cells and are instrumental for healing. This action is mediated by the productive interaction with muscle stem cells. ${ }^{7,8}$ In contrast, the accumulation of conventional $\mathrm{CD}^{+}$or $\mathrm{CD}^{+} \mathrm{T}$ lymphocytes reflects persistent inflammatory and immune-mediated injury, such as that taking place as a consequence of muscular dystrophy or inflammatory myopathies. ${ }^{72,73}$ Figure 3 depicts some cellular players of muscle regeneration.

Muscle stem cells fail to activate their regenerative potential in the absence of the inflammatory response. ${ }^{66,70,74}$ The release of DAMPs/alarmins as a consequence of cell death and of immune cell activation might be important in the reciprocal activation/regulation of immune and of muscle stem/progenitor cells. The availability of novel elegant genetic inducible cell-fate mapping models will be valuable for the better understanding of the overall scenario. In skeletal muscle, immune responses depend almost completely on recruited inflammatory cells that decode the need of the tissue for healing and broadcast the news to resident stem/ progenitor cells. Thus, the characteristics of immune cell activation are critical.

\section{The Predators: Macrophages Scavenge Muscle Debris}

Despite the significant amount of cell death that occurs in inflamed muscle, under physiological conditions cell remnants are extremely rare, indicating that the debris disposal mechanisms are effective. Macrophages are essential. Their depletion results in the persistence of cell remnants, deriving either from necrotic fibers, dying progenitor cells or inflammatory leukocytes. Moreover, upon depletion of macrophages muscle regeneration is severely compromised (reviewed in Bosurgi et al. ${ }^{70}$ and Tidballand and Villalta ${ }^{71}$ ). Macrophages and muscle regeneration are therefore closely associated. The dissection of the macrophage plasticity in the tissue has allowed in the past years to define more precisely the hierarchy of events in the maintenance of muscle homeostasis.

Macrophages that infiltrate the tissue at early time points after injury are classically activated inflammatory macrophages, also referred to as 'M1' cells. They generate inflammatory cytokines and sustain the activation and the proliferation of muscle stem cells. ${ }^{75}$ 'Alternatively activated' or 'M2' macrophages predominate during the resolution phases of the damage when they regulate the termination of the inflammatory responses. ${ }^{69,76}$ Monocyte-derived macrophages undergo dynamic transitions between $\mathrm{M} 1$ and $\mathrm{M} 2$ and this timely transition is increasingly felt to be the key to muscle homeostasis. ${ }^{77,78}$

MAP kinase phosphatase-1 (MKP-1) regulates cell remnant disposal, macrophage transition and muscle healing. ${ }^{79,80}$ Gene expression analyses on sorted $\mathrm{MKP}-1^{-/-}$muscle macrophages suggest that MKP-1 regulates the inflammatory response as well as the macrophage polarization via p38 MAPK downregulation. Another enzyme, the AMP-activated protein kinase (AMPK)-a1, which 'senses' the cellular energy levels, also regulates the inflammatory status of macrophages. AMPK-a1-deficient macrophages fail to undergo an alternative M2 activation upon the recognition of apoptotic cells, ${ }^{81}$ suggesting a relationship between macrophage polarization and debris disposal. Studies on the cAMP response element-binding protein (CREB), a transcription factor involved in the upregulation of M2-associated genes, further strengthen the existence of a cause-effect relationship between recognition of apoptotic cells and acquisition of the macrophage ability to guide muscle stem cell regenerative potential. Deletion of CREB-binding sites from the $\mathrm{C} / \mathrm{EBP} \beta$ gene promoter indeed blocks the downstream induction of regulatory genes. Debris are effectively cleared but muscle fiber regeneration is severely jeopardized. ${ }^{76}$ In contrast, other crucial pathways, such as those coordinated by myeloid hypoxia-inducible factors, are apparently dispensable for M1/M2 shift and muscle healing after sterile injury. ${ }^{82}$ Of importance, other cells, including eosinophils and FAPs, are apparently involved in the clearance of necrotic muscle debris in experimental models ${ }^{56,83}$ (Figure 2). Even myoblasts in vitro appear to be endowed with the ability to internalize apoptotic myoblasts. ${ }^{84}$ The actual contribution of these unconventional phagocytes in physiological conditions and their impact on the skeletal muscle immunobiology will require further study.

The expression of phagocytic tags by dying cells is fundamental for their recognition and clearance. ${ }^{85-88}$ Relatively little is known on the role of phagocytic tags in the skeletal muscle. Exposure of anionic phospholipids, such as phosphatidylserine (PS), is among the best-characterized events involving in apoptotic cell recognition. ${ }^{89}$ Induction of fusion appears to cause death of a fraction of myoblasts. ${ }^{90}$ Intriguingly, PS recognition is important for the formation of myotubes. ${ }^{84,91,92}$ In vivo, expression of the well-characterized PS receptor BAI1 is required for muscle regeneration, further strengthening the link between cell death in the tissue, exposure and recognition of PS and successful tissue healing. ${ }^{84}$

Phagocytes uphold muscle stem cell differentiation and function. Conversely, muscle stem cells influence macrophages. This is the case for vessel-associated muscle stem cells (also referred to as mesoangioblasts), myogenic precursors that express pericyte markers and cross vessel walls; ${ }^{69,93,94}$ they sustain the ability of macrophages to clear apoptotic cells and promote the expression of genes associated with their alternative activation. ${ }^{95}$

\section{Outcomes of Defective Apoptotic Cell Clearance: Maladaptive Muscle Remodeling with Ectopic Tissue Deposition}

The skeletal muscle homeostasis is in most cases maintained upon injury. However, in some cases the original damaging noxa cannot be removed, such as in muscular dystrophies ${ }^{96}$ or in immune-mediated inflammatory myopathies (IIM). ${ }^{97}$ As a consequence, inflammation persists and repeated cycles of necrosis and regeneration ensue, eventually causing the substitution of myofibers with noncontractile elements such as fat, fibrotic tissue or bone. ${ }^{98}$

Acellular lipid droplets and adipocytes, defined based on triglycerides and cholesterol ester content and by the expression of peroxisome proliferator-activated receptor $\gamma 2$, perilipin, leptin, adiponectin and fatty acid-binding protein 4, account for the muscle fat. ${ }^{99}$ Intra- and intermuscular fat is a histopathological hallmark of persistently damaged 


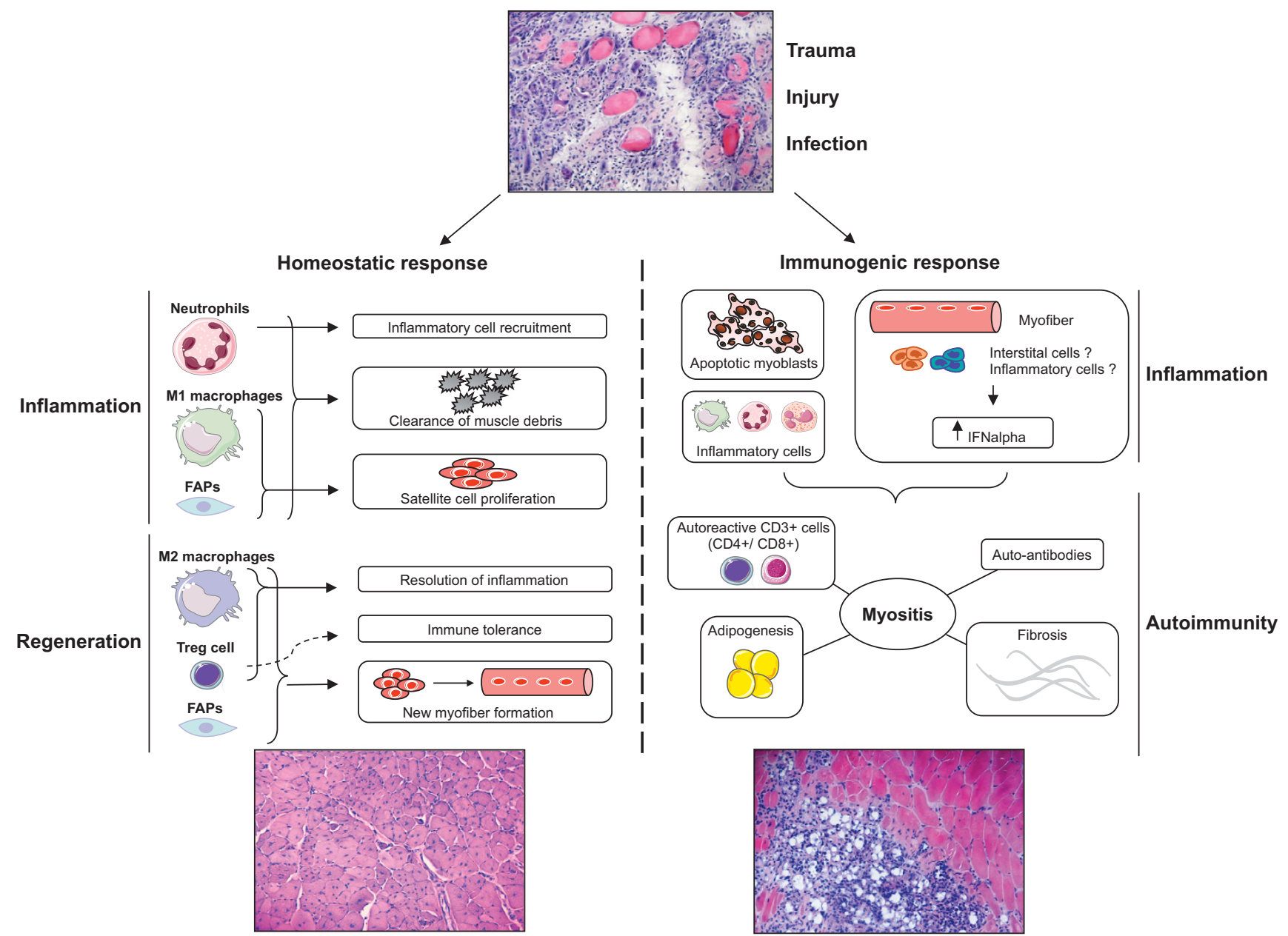

Figure 4 Adaptive and maladaptive muscle remodeling. Skeletal muscle homeostasis is in most cases maintained upon injury. Macrophages and FAPs contribute to effective debris disposal and together with Treg cells they sustain satellite cell proliferation/differentiation and contribute to the resolution of inflammation (left panel). However, in some cases the original damaging noxa cannot be removed and maladaptive muscle remodeling takes place. In particular, in inflammatory myopathies skeletal muscle is characterized by persistent inflammation with recruitment of autoreactive T cells $(C D 4+/ C D 8+)$, production of autoantibodies and frequently the substitution of myofibers with noncontractile elements such as fat and fibrotic tissue. We propose that the simultaneous presence of inflammation, apoptotic myoblasts and type I interferon could participate into the initiation of a self-sustaining autoimmunity (right panel)

and inflamed muscles. Cells of mesenchymal origin yield adipocytes in vitro and in vivo, including satellite cells, fibroblasts, myoendothelial cells, pericytes, mesoangioblasts, PW1-expressing cells and FAPs. ${ }^{99}$

FAPs sustain satellite cell-driven myogenesis or directly differentiate into myoblasts in physiological conditions. ${ }^{54}$ When regeneration fails because of satellite cell defect ${ }^{55,100}$ and/or inadequate inflammatory response, ${ }^{83}$ they generate adipocytes or differentiate into myofibroblasts. Myofibroblasts physiologically proliferate and synthesize extracellular matrix as scaffold to new fibers in reparative myogenesis. Upon injury resolution they induce matrix remodeling and degradation before undergoing apoptosis. ${ }^{101}$ The counterpart of this event, that is, a self-perpetuating matrix deposition, eventually causing fibrosis, is characteristic of the persistently inflamed skeletal muscle. ${ }^{56,102-104}$

Heterotopic ossification may occur after severe traumatic skeletal muscle damage or neurological injury ${ }^{105}$ and seems to result from inappropriate differentiation of mesenchymal progenitors. Persisting inflammation, inadequate phagocytosis and bone morphogenetic proteins activation are all thought to contribute. ${ }^{106,107} \mathrm{~A}$ rare genetic disorder, fibrodysplasia ossificans progessiva, associated with the activating mutation in the bone morphogenetic protein type I receptor ALK2 clearly highlights the link. ${ }^{108}$

\section{Outcomes of Defective Apoptotic Cell Clearance: Autoimmunity}

IIM leads to disability, decreased quality of life and increased mortality. ${ }^{109}$ Persistent inflammation with recruitment of autoreactive $T$ cells characterizes the skeletal muscle. ${ }^{110,111}$ Available evidence strongly supports the autoimmune underpinnings of IIM and commonly targeted autoantigens include proteins involved in DNA transcription or protein synthesis, such as the histidyl-tRNA synthase (HisRS). ${ }^{73,112-114}$ Regenerating fibers appear a preferential 
source of autoantigens, suggesting that regeneration plays an important role in initiating and/or perpetuating the disease process. ${ }^{114}$ However, the signals that confer immunogenicity to a rather limited set of ubiquitously expressed intracellular antigens have only partially been characterized. Modifications of the autoantigens, including enhanced expression, altered distribution and/or access to phagocytes/APCs for processing, might be mechanistically important. Adjuvant signals selectively generated during various forms of inflammation might further influence the antigen presentation in given tissues. In turn, this might contribute to the onset and the maintenance of autoimmune responses targeting ubiquitously expressed antigens while selectively damaging particular tissues, such as the skeletal muscle in IIM. ${ }^{115}$

We have recently observed that despite its abundant expression in myogenic precursors within inflamed muscles, HisRS is not by itself fully immunogenic. Lack of immunogenicity could depend on: (1) the lack of access of an intracellular moiety to APCs that must process and cross-present epitopes to autoreactive T cells; and/or (2) a still noncharacterized action in the maintenance of tolerance of Treg populations that are physiologically recruited during regeneration of the tissue. ${ }^{7,8}$

Apoptotic HisRS-expressing myogenic precursors might represent a preferential substrate for phagocytic uptake and processing by APCs. In fact, several observations support the relevance of the link between apoptosis and autoimmunity that has been extensively studied in other contexts. For example, the programmed death of keratinocytes influences the structure and the pattern of expression of intracellular antigens that are selectively redistributed to apoptotic bleb structures. ${ }^{116,117}$ In turn, apoptotic cells represent immunogenic substrate for uptake and presentation to autoreactive lymphocytes.

Protective immunity targeting viral and neoplastic intracellular antigens and the establishment of self-sustaining systemic autoimmune diseases are among the in vivo consequences of the T-cell activation. ${ }^{118-124}$ Indeed, treatment with cancer cells killed with lethal doses of doxorubicin vaccinates mice against a subsequent challenge with living neoplastic cells of the same type and leads to the identification of the 'immunogenic cell death'. ${ }^{125,126}$ Various signals and processes influence the immunogenic outcome of the cell death including the action of DAMPs, like cell surface-exposed calreticulin, extracellular ATP and HMGB1, and the processes that make the DAMP available in the extracellular environment, such as endoplasmic reticulum (ER) stress, autophagy and plasma membrane permeabilization disruption upon necrosis. Implications of these concepts are being actively studied in particular in the oncology field and consensus guidelines for the detection of immunogenic cell death have been recently published. ${ }^{127}$

Of interest, virtually all the processes involved in facilitating DAMP release and biological action are well characterized in the inflamed skeletal muscle: HMGB1 is a critical signal not only in the physiological remodeling of the injured tissue (see above), but also plays well-characterized role in IIM. ${ }^{41,128}$ Autophagy is critically involved in the physiologic response of the muscle to stressful conditions (see above). Impaired autophagosome maturation with consequent accumulation of multiprotein aggregates is a key factor in the myofiber degeneration characteristic of inclusion body myopathy, while evidence of sustained autophagic flux is detectable in IIM muscles. ${ }^{129}$ Upregulation of the expression of $\mathrm{MHC}$ class I molecules in skeletal muscle fibers is an early feature of IIM and ectopic expression of the molecule induced ER stress response and resulted in a disease that shares several features with human IIM. ${ }^{130,131}$

Considering that muscle injury and the associated inflammatory response represent rather common event in vivo, ${ }^{109}$ the relative rarity of IIM indicates that a number of events must simultaneously occur to set the stage for self-sustaining autoimmunity. We have recently observed that apoptotic myoblasts are immunogenic only if appropriate adjuvants are provided in the injured/regenerating muscle. ${ }^{132}$ Specifically, apoptotic myoblasts in the presence of stimuli activating TLR7-dependent inflammatory pathways and the generation of type I interferon, a key cytokine expressed in IIM patients and physiologically produced by myogenic precursors, ${ }^{133}$ induce the production of anti-HisRS antibodies, linked to persistent leukocyte infiltration of the tissue, reproducing several features that occur in the tissue of patients with $\mathrm{IIM}^{132}$ (Figure 4).

\section{Conflict of Interest}

The authors declare no conflict of interest.

1. Streilein JW. Ocular immune privilege: therapeutic opportunities from an experiment of nature. Nat Rev Immunol 2003; 3: 879-889.

2. Niederkorn JY. See no evil, hear no evil, do no evil: the lessons of immune privilege. Nat Immunol 2006; 7: 354-359.

3. Matzingerand P, Kamala T. Tissue-based class control: the other side of tolerance. Nat Rev Immunol 2011; 11: 221-230.

4. Niederkornand JY, Stein-Streilein J. History and physiology of immune privilege. Ocul Immunol Inflamm 2010; 18: 19-23.

5. Perezand VL, Caspi RR. Immune mechanisms in inflammatory and degenerative eye disease. Trends Immunol 2015; 36: 354-363.

6. Gadani SP, Walsh JT, Lukens JR, Kipnis J. Dealing with danger in the CNS: the response of the immune system to injury. Neuron 2015; 87: 47-62.

7. Burzyn D, Kuswanto W, Kolodin D, Shadrach JL, Cerletti M, Jang $Y$ et al. A special population of regulatory T cells potentiates muscle repair. Cell 2013; 155: 1282-1295.

8. Castiglioni A, Corna G, Rigamonti E, Basso V, Vezzoli M, Monno A et al. FOXP3+ T cells recruited to sites of sterile skeletal muscle injury regulate the fate of satellite cells and guide effective tissue regeneration. PLOS One 2015; 10: e0128094.

9. Smith HK, Maxwell L, Martyn JA, Bass JJ. Nuclear DNA fragmentation and morphological alterations in adult rabbit skeletal muscle after short-term immobilization. Cell Tissue Res 2000; 302: 235-241.

10. Siu PM, Pistilli EE, Butler DC, Alway SE. Aging influences cellular and molecular responses of apoptosis to skeletal muscle unloading. Am J Physiol Cell Physiol 2005; 288: C338-C349.

11. Dupont-Versteegden EE, Strotman BA, Gurley CM, Gaddy D, Knox M, Fluckey JD et al. Nuclear translocation of EndoG at the initiation of disuse muscle atrophy and apoptosis is specific to myonuclei. Am J Physiol Regul Integr Comp Physiol 2006; 291: R1730-R1740.

12. Andrianjafiniony T, Dupre-Aucouturier S, Letexier D, Couchoux H, Desplanches D. Oxidative stress, apoptosis, and proteolysis in skeletal muscle repair after unloading. Am J Physiol Cell Physiol 2010; 299: C307-C315.

13. Allen DL, Roy RR, Edgerton VR. Myonuclear domains in muscle adaptation and disease. Muscle Nerve 1999; 22: 1350-1360.

14. Marzetti E, Calvani R, Cesari M, Buford TW, Lorenzi M, Behnke BJ et al. Mitochondrial dysfunction and sarcopenia of aging: from signaling pathways to clinical trials. Int $J$ Biochem Cell Biol 2013; 45: 2288-2301.

15. Tewsand DS, Goebel HH. DNA fragmentation and BCL-2 expression in infantile spinal muscular atrophy. Neuromuscul Disord 1996; 6: 265-273.

16. Bruusgaard JC, Egner IM, Larsen TK, Dupre-Aucouturier S, Desplanches D, Gundersen K. No change in myonuclear number during muscle unloading and reloading. $J$ Appl Physiol (1985)2012; 113: 290-296.

17. Singhaland N, Martin PT. A role for Galgt1 in skeletal muscle regeneration. Skelet Muscle 2015; 5 : 3. 
18. Bonaldoand P, Sandri M. Cellular and molecular mechanisms of muscle atrophy. Dis Model Mech 2013; 6: 25-39.

19. Neely KA, Planetta PJ, Prodoehl J, Corcos DM, Comella CL, Goetz CG et al. Force control deficits in individuals with Parkinson's disease, multiple systems atrophy, and progressive supranuclear palsy. PLoS One 2013; 8: e58403.

20. Wohlgemuth SE, Seo AY, Marzetti E, Lees HA, Leeuwenburgh C. Skeletal muscle autophagy and apoptosis during aging: effects of calorie restriction and life-long exercise. Exp Gerontol 2010; 45: 138-148.

21. Marzetti E, Lawler JM, Hiona A, Manini T, Seo AY, Leeuwenburgh C. Modulation of ageinduced apoptotic signaling and cellular remodeling by exercise and calorie restriction in skeletal muscle. Free Radic Biol Med 2008; 44: 160-168.

22. Pollack M, Phaneuf S, Dirks A, Leeuwenburgh C. The role of apoptosis in the normal aging brain, skeletal muscle, and heart. Ann NY Acad Sci 2002; 959: 93-107.

23. Dirksand A, Leeuwenburgh C. Apoptosis in skeletal muscle with aging. Am J Physiol Regul Integr Comp Physiol 2002; 282: R519-R527.

24. Martinez-Lopez N, Athonvarangkul D, Singh R. Autophagy and aging. Adv Exp Med Biol. 2015; 847: 73-87.

25. Vezzoli M, Castellani P, Corna G, Castiglioni A, Bosurgi L, Monno A et al. High-mobility group box 1 release and redox regulation accompany regeneration and remodeling of skeletal muscle. Antioxid Redox Signal 2011; 15: 2161-2174.

26. Lopes-Ferreira M, Nunez J, Rucavado A, Farsky SH, Lomonte B, Angulo Y et al. Skeletal muscle necrosis and regeneration after injection of Thalassophryne nattereri (niquim) fish venom in mice. Int J Exp Pathol 2001; 82: 55-64.

27. Podhorska-Okolow M, Sandri M, Zampieri S, Brun B, Rossini K, Carraro U. Apoptosis of myofibres and satellite cells: exercise-induced damage in skeletal muscle of the mouse. Neuropathol Appl Neurobiol 1998; 24: 518-531.

28. Arslan S, Erdem S, Sivri A, Hascelik Z, Tan E. Exercise-induced apoptosis of rat skeletal muscle and the effect of meloxicam. Rheumatol Int 2002; 21: 133-136.

29. Haralambieand G, Senser L. Metabolic changes in man during long-distance swimming Eur J Appl Physiol Occup Physiol 1980; 43: 115-125.

30. Proskeand U, Allen TJ. Damage to skeletal muscle from eccentric exercise. Exerc Sport Sci Rev 2005;. 33: 98-104.

31. Behringer M, Montag J, Franz A, McCourt ML, Mester J, Nosaka KK. Exhaustive exercisea near death experience for skeletal muscle cells? Med Hypotheses 2014; 83: 758-765.

32. Vezzoli M, Castellani P, Campana L, Corna G, Bosurgi L, Manfredi AA et al. Redox remodeling: a candidate regulator of HMGB1 function in injured skeletal muscle. Ann NY Acad Sci 2010; 1209: 83-90.

33. Bianchiand ME, Manfredi AA. High-mobility group box 1 (HMGB1) protein at the crossroads between innate and adaptive immunity. Immunol Rev 2007; 220: 35-46.

34. Venereau E, Casalgrandi M, Schiraldi M, Antoine DJ, Cattaneo A, De Marchis F et al. Mutually exclusive redox forms of HMGB1 promote cell recruitment or proinflammatory cytokine release. J Exp Med 2012; 209: 1519-1528.

35. Venereau E, Schiraldi M, Uguccioni M, Bianchi ME. HMGB1 and leukocyte migration during trauma and sterile inflammation. Mol Immunol 2013; 55: 76-82.

36. Janko C, Filipovic M, Munoz LE, Schorn C, Schett G, Ivanovic-Burmazovic I et al. Redox modulation of HMGB1-related signaling. Antioxid Redox Signal 2014; 20: 1075-1085.

37. Maugeri N, Rovere-Querini P, Baldini M, Baldissera E, Sabbadini MG, Bianchi ME et al. Oxidative stress elicits platelet/leukocyte inflammatory interactions via HMGB1: a candidate for microvessel injury in sytemic sclerosis. Antioxid Redox Signal 2014; 20: $1060-1074$.

38. Campana L, Bosurgi L, Bianchi ME, Manfredi AA, Rovere-Querini P. Requirement of HMGB1 for stromal cell-derived factor-1/CXCL12-dependent migration of macrophages and dendritic cells. J Leukoc Biol 2009; 86: 609-615.

39. Campana L, Santarella F, Esposito A, Maugeri N, Rigamonti E, Monno A et al. Leukocyte HMGB1 is required for vessel remodeling in regenerating muscles. J Immunol 2014; 192: $5257-5264$.

40. Zong M, Bruton JD, Grundtman C, Yang H, Li JH, Alexanderson $\mathrm{H}$ et al. TLR4 as receptor for HMGB1 induced muscle dysfunction in myositis. Ann Rheum Dis 2013; 72: 1390-1399.

41. Grundtman C, Bruton J, Yamada T, Ostberg T, Pisetsky DS, Harris HE et al. Effects of HMGB1 on in vitro responses of isolated muscle fibers and functional aspects in skeletal muscles of idiopathic inflammatory myopathies. FASEB J 2010; 24: 570-578.

42. Tews DS. Apoptosis and muscle fibre loss in neuromuscular disorders. Neuromuscul Disord 2002; 12: 613-622.

43. Tews DS. Muscle-fiber apoptosis in neuromuscular diseases. Muscle Nerve 2005; 32: 443-458.

44. Matsumuraand K, Campbell KP. Deficiency of dystrophin-associated proteins: a common mechanism leading to muscle cell necrosis in severe childhood muscular dystrophies. Neuromuscul Disord 1993; 3: 109-118

45. Tewsand DS, Goebel HH. DNA-fragmentation and expression of apoptosis-related proteins in muscular dystrophies. Neuropathol Appl Neurobiol 1997; 23: 331-338.

46. Sugiura T, Murakawa $Y$, Nagai A, Kondo M, Kobayashi S. Fas and Fas ligand interaction induces apoptosis in inflammatory myopathies: CD4+ T cells cause muscle cell injury directly in polymyositis. Arthritis Rheum 1999; 42: 291-298.

47. Zhao Y, Fedczyna TO, McVicker V, Caliendo J, Li H, Pachman LM. Apoptosis in the skeletal muscle of untreated children with juvenile dermatomyositis: impact of duration of untreated disease. Clin Immunol 2007; 125: 165-172.
48. Maugeri N, Campana L, Gavina M, Covino C, De Metrio M, Panciroli C et al. Activated platelets present high mobility group box 1 to neutrophils, inducing autophagy and promoting the extrusion of neutrophil extracellular traps. J Thromb Haemost 2014; 12: 2074-2088.

49. Manfredi AA, Covino $C$, Rovere-Querini $P$, Maugeri N. Instructive influences of phagocytic clearance of dying cells on neutrophil extracellular trap generation. Clin Exp Immuno/ 2015, 179: 24-29.

50. Oklu R, Albadawi $\mathrm{H}$, Jones JE, Yoo HJ, Watkins MT. Reduced hind limb ischemiareperfusion injury in Toll-like receptor-4 mutant mice is associated with decreased neutrophil extracellular traps. J Vasc Surg 2013; 58: 1627-1636.

51. Dentice M, Ambrosio R, Damiano V, Sibilio A, Luongo C, Guardiola O et al. Intracellular inactivation of thyroid hormone is a survival mechanism for muscle stem cell proliferation and lineage progression. Cell Metab 2014; 20: 1038-1048.

52. Abou-Khalil R, Le Grand F, Pallafacchina G, Valable S, Authier FJ, Rudnicki MA et al. Autocrine and paracrine angiopoietin 1/Tie-2 signaling promotes muscle satellite cell selfrenewal. Cell Stem Cell 2009; 5: 298-309.

53. Francois S, D'Orlando C, Fatone T, Touvier T, Pessina P, Meneveri R et al. Necdin enhances myoblasts survival by facilitating the degradation of the mediator of apoptosis CCAR1/CARP1. PLoS One 2012; 7: e43335.

54. Joe AW, Yi L, Natarajan A, Le Grand F, So L, Wang J et al. Muscle injury activates resident fibro/adipogenic progenitors that facilitate myogenesis. Nat Cell Biol 2010; 12: 153-163.

55. Uezumi A, Fukada S, Yamamoto N, Takeda S, Tsuchida K. Mesenchymal progenitors distinct from satellite cells contribute to ectopic fat cell formation in skeletal muscle. Nat Cell Biol 2010; 12: 143-152.

56. Lemos DR, Babaeijandaghi F, Low M, Chang CK, Lee ST, Fiore D et al. Nilotinib reduces muscle fibrosis in chronic muscle injury by promoting TNF-mediated apoptosis of fibro/ adipogenic progenitors. Nat Med 2015; 21: 786-794.

57. Serhanand CN, Savill J. Resolution of inflammation: the beginning programs the end. Nat Immunol 2005; 6: 1191-1197.

58. Mauro A. Satellite cell of skeletal muscle fibers. J Biophys Biochem Cytol 1961; 9: 493-495.

59. Zammit PS, Relaix F, Nagata Y, Ruiz AP, Collins CA, Partridge TA et al. Pax7 and myogenic progression in skeletal muscle satellite cells. J Cell Sci 2006; 119: 1824-1832.

60. Dhawanand J, Rando TA. Stem cells in postnatal myogenesis: molecular mechanisms of satellite cell quiescence, activation and replenishment. Trends Cell Biol 2005; 15: 666-673.

61. McKinnell IW, Parise G, Rudnicki MA. Muscle stem cells and regenerative myogenesis. Curr Top Dev Biol 2005; 71: 113-130.

62. Relaixand F, Zammit PS. Satellite cells are essential for skeletal muscle regeneration: the cell on the edge returns centre stage. Development 2012; 139: 2845-2856.

63. Buckingham M. Skeletal muscle formation in vertebrates. Curr Opin Genet Dev 2001, 11: $440-448$.

64. Brigitte M, Schilte $\mathrm{C}$, Plonquet A, Baba-Amer Y, Henri A, Charlier $\mathrm{C}$ et al. Muscle resident macrophages control the immune cell reaction in a mouse model of notexin-induced myoinjury. Arthritis Rheum 2010; 62: 268-279.

65. Yokota M, Suzuki K, Tokoyoda K, Meguro K, Hosokawa J, Tanaka S et al. Roles of mast cells in the pathogenesis of inflammatory myopathy. Arthritis Res Ther 2014; 16: R72.

66. Tidball JG, Dorshkind K, Wehling-Henricks M. Shared signaling systems in myeloid cell-mediated muscle regeneration. Development 2014; 141: 1184-1196.

67. Tidball JG, Berchenko E, Frenette J. Macrophage invasion does not contribute to muscle membrane injury during inflammation. J Leukoc Biol 1999; 65: 492-498.

68. Chazaud B. Macrophages: supportive cells for tissue repair and regeneration. Immunobiology 2014; 219: 172-178.

69. Bosurgi L, Corna G, Vezzoli M, Touvier T, Cossu G, Manfredi AA et al. Transplanted mesoangioblasts require macrophage $\mathrm{IL}-10$ for survival in a mouse model of muscle injury. J Immunol. 2012; 188: 6267-6277.

70. Bosurgi L, Manfredi AA, Rovere-Querini P. Macrophages in injured skeletal muscle: a perpetuum mobile causing and limiting fibrosis, prompting or restricting resolution and regeneration. Front Immunol 2011; 2: 62.

71. Tidballand JG, Villalta SA. Regulatory interactions between muscle and the immune system during muscle regeneration. Am J Physiol Regul Integr Comp Physiol 2010; 298: R1173-R1187.

72. Villalta SA, Rosenthal W, Martinez L, Kaur A, Sparwasser T, Tidball JG et al. Regulatory T cells suppress muscle inflammation and injury in muscular dystrophy. Sci Transl Med 2014; 6: 258ra142.

73. Venalisand $\mathrm{P}$, Lundberg IE. Immune mechanisms in polymyositis and dermatomyositis and potential targets for therapy. Rheumatology Oxford) 2014; 53: 397-405.

74. Tidballand JG, Wehling-Henricks M. Macrophages promote muscle membrane repair and muscle fibre growth and regeneration during modified muscle loading in mice in vivo. J Physiol 2007; 578: 327-336

75. Arnold L, Henry A, Poron F, Baba-Amer Y, van Rooijen N, Plonquet A et al. Inflammatory monocytes recruited after skeletal muscle injury switch into antiinflammatory macrophages to support myogenesis. J Exp Med 2007; 204: 1057-1069.

76. Ruffell D, Mourkioti F, Gambardella A, Kirstetter P, Lopez RG, Rosenthal N et al. A CREB$\mathrm{C} /$ EBPbeta cascade induces M2 macrophage-specific gene expression and promotes muscle injury repair. Proc Natl Acad Sci USA 2009; 106: 17475-17480.

77. Lawrenceand T, Natoli G. Transcriptional regulation of macrophage polarization: enabling diversity with identity. Nat Rev Immunol 2011; 11: 750-761. 
78. Mosserand DM, Edwards JP. Exploring the full spectrum of macrophage activation. Nat Rev Immunol 2008; 8: 958-969.

79. Perdiguero E, Sousa-Victor P, Ruiz-Bonilla V, Jardi M, Caelles C, Serrano AL et al. p38/ MKP-1-regulated AKT coordinates macrophage transitions and resolution of inflammation during tissue repair. J Cell Biol 2011; 195: 307-322.

80. Perdiguero E, Kharraz Y, Serrano AL, Munoz-Canoves P. MKP-1 coordinates ordered macrophage-phenotype transitions essential for stem cell-dependent tissue repair. Cell Cycle 2012; 11: 877-886.

81. Mounier R, Theret M, Arnold L, Cuvellier S, Bultot L, Goransson 0 et al. AMPKalpha1 regulates macrophage skewing at the time of resolution of inflammation during skeletal muscle regeneration. Cell Metab 2013; 18: 251-264.

82. Gondin J, Theret M, Duhamel G, Pegan K, Mathieu JR, Peyssonnaux C et al. Myeloid HIFs are dispensable for resolution of inflammation during skeletal muscle regeneration. J Immunol 2015; 194: 3389-3399.

83. Heredia JE, Mukundan L, Chen FM, Mueller AA, Deo RC, Locksley RM et al. Type 2 innate signals stimulate fibro/adipogenic progenitors to facilitate muscle regeneration. Cell 2013, 153: 376-388.

84. Hochreiter-Hufford AE, Lee CS, Kinchen JM, Sokolowski JD, Arandjelovic S, Call JA et al. Phosphatidylserine receptor BAl1 and apoptotic cells as new promoters of myoblast fusion. Nature 2013; 497: 263-267.

85. Arandjelovicand S, Ravichandran KS. Phagocytosis of apoptotic cells in homeostasis. Nat Immunol 2015; 16: 907-917.

86. Poon IK, Lucas CD, Rossi AG, Ravichandran KS. Apoptotic cell clearance: basic biology and therapeutic potential. Nat Rev Immunol 2014; 14: 166-180.

87. Kimani SG, Geng K, Kasikara C, Kumar S, Sriram G, Wu Y et al. Contribution of defective $P S$ recognition and efferocytosis to chronic inflammation and autoimmunity. Front Immunol 2014; $5: 566$.

88. Wickman G, Julian L, Olson MF. How apoptotic cells aid in the removal of their own cold dead bodies. Cell Death Differ 2012; 19: 735-742.

89. Segawaand K, Nagata S. An apoptotic 'eat me' signal: phosphatidylserine exposure. Trends Cell Biol 2015; 25: 639-650.

90. Dee K, Freer M, Mei Y, Weyman CM. Apoptosis coincident with the differentiation of skeletal myoblasts is delayed by caspase 3 inhibition and abrogated by MEK-independent constitutive Ras signaling. Cell Death Differ. 2002; 9: 209-218.

91. van den Eijnde SM, van den Hoff MJ, Reutelingsperger $C P$, van Heerde WL, Henfling ME Vermeii-Keers $\mathrm{C}$ et al. Transient expression of phosphatidylserine at cell-cell contact areas is required for myotube formation. J Cell Sci 2001; 114: 3631-3642.

92. Jeongand J, Conboy IM. Phosphatidylserine directly and positively regulates fusion of myoblasts into myotubes. Biochem Biophys Res Commun 2011; 414: 9-13.

93. Sampaolesi M, Torrente Y, Innocenzi A, Tonlorenzi R, D'Antona G, Pellegrino MA et al. Cell therapy of alpha-sarcoglycan null dystrophic mice through intra-arterial delivery of mesoangioblasts. Science 2003; 301: 487-492.

94. Lolmede K, Campana L, Vezzoli M, Bosurgi L, Tonlorenzi R, Clementi E et al. Inflammatory and alternatively activated human macrophages attract vessel-associated stem cells, relying on separate HMGB1- and MMP-9-dependent pathways. J Leukoc Biol 2009; 85 779-787.

95. Bosurgi L, Brunelli S, Rigamonti E, Monno A, Manfredi AA, Rovere-Querini P. Vesselassociated myogenic precursors control macrophage activation and clearance of apoptotic cells. Clin Exp Immunol 2015; 179: 62-67.

96. Triplett WT, Baligand C, Forbes SC, Willcocks RJ, Lott DJ, DeVos S et al. Chemical shift-based MRI to measure fat fractions in dystrophic skeletal muscle. Magn Reson Med 2013; 72: 8-19.

97. Reimersand CD, Finkenstaedt M. Muscle imaging in inflammatory myopathies. Curr Opin Rheumatol 1997; 9: 475-485.

98. Barany M, Venkatasubramanian PN, Mok E, Siegel IM, Abraham E, Wycliffe ND et al. Quantitative and qualitative fat analysis in human leg muscle of neuromuscular diseases by 1H MR spectroscopy in vivo. Magn Reson Med 1989; 10: 210-226.

99. Sciorati C, Clementi E, Manfredi AA, Rovere-Querini P. Fat deposition and accumulation in the damaged and inflamed skeletal muscle: cellular and molecular players. Cell Mol Life Sci 2015; 72: 2135-2156.

100. Mozzetta C, Consalvi S, Saccone V, Tierney M, Diamantini A, Mitchell KJ et al. Fibroadipogenic progenitors mediate the ability of HDAC inhibitors to promote regeneration in dystrophic muscles of young, but not old Mdx mice. EMBO Mol Med 2013; 5: 626-639.

101. Hinz B. Formation and function of the myofibroblast during tissue repair. J Invest Dermatol 2007: 127: 526-537.

102. Summan M, Warren GL, Mercer RR, Chapman R, Hulderman $\mathrm{T}$, Van Rooijen $\mathrm{N}$ et al. Macrophages and skeletal muscle regeneration: a clodronate-containing liposome depletion study. Am J Physiol Regul Integr Comp Physiol 2006; 290: R1488-R1495.

103. Zordan P, Rigamonti E, Freudenberg K, Conti V, Azzoni E, Rovere-Querini $\mathrm{P}$ et al. Macrophages commit postnatal endothelium-derived progenitors to angiogenesis and restrict endothelial to mesenchymal transition during muscle regeneration. Cell Death Dis 2014; 5: e1031.

104. Rigamonti E, Zordan P, Sciorati C, Rovere-Querini P, Brunelli S. Macrophage plasticity in skeletal muscle repair. Biomed Res Int 2014; 2014: 560629

105. Balboni TA, Gobezie R, Mamon HJ. Heterotopic ossification: pathophysiology, clinical features, and the role of radiotherapy for prophylaxis. Int J Radiat Oncol Biol Phys 2006; 65: $1289-1299$.
106. Genet F, Kulina I, Vaquette C, Torossian F, Millard S, Pettit AR et al. Neurological heterotopic ossification following spinal cord injury is triggered by macrophage-mediated inflammation in muscle. J Pathol 2015; 236: 229-240.

107. Shore EM, Xu M, Feldman GJ, Fenstermacher DA, Cho TJ, Choi IH et al. A recurrent mutation in the BMP type I receptor ACVR1 causes inherited and sporadic fibrodysplasia ossificans progressiva. Nat Genet 2006; 38: 525-527.

108. Ramirez DM, Ramirez MR, Reginato AM, Medici D. Molecular and cellular mechanisms of heterotopic ossification. Histol Histopathol 2014; 29: 1281-1285.

109. Rayavarapu S, Coley W, Kinder TB, Nagaraju K. Idiopathic inflammatory myopathies: pathogenic mechanisms of muscle weakness. Skeletal Muscle 2013; 3: 13

110. Bender A, Ernst N, Iglesias A, Dornmair K, Wekerle H, Hohlfeld R. T cell receptor repertoire in polymyositis: clonal expansion of autoaggressive CD8+ T cells. J Exp Med 1995; 181: 1863-1868.

111. Hohlfeldand R, Engel AG. Coculture with autologous myotubes of cytotoxic T cells isolated from muscle in inflammatory myopathies. Ann Neurol 1991; 29: 498-507.

112. Stone KB, Oddis CV, Fertig N, Katsumata Y, Lucas M, Vogt M et al. Anti-Jo-1 antibody levels correlate with disease activity in idiopathic inflammatory myopathy. Arthritis Rheum 2007; 56: 3125-3131.

113. Mammen AL, Casciola-Rosen LA, Hall JC, Christopher-Stine L, Corse AM, Rosen A. Expression of the dermatomyositis autoantigen Mi-2 in regenerating muscle. Arthritis Rheum 2009; 60: 3784-3793.

114. Casciola-Rosen L, Nagaraju K, Plotz P, Wang K, Levine S, Gabrielson E et al. Enhanced autoantigen expression in regenerating muscle cells in idiopathic inflammatory myopathy. J Exp Med 2005; 201: 591-601.

115. Suber TL, Casciola-Rosen L, Rosen A. Mechanisms of disease: autoantigens as clues to the pathogenesis of myositis. Nat Clin Pract Rheumatol 2008; 4: 201-209.

116. Casciola-Rosen LA, Anhalt G, Rosen A. Autoantigens targeted in systemic lupus erythematosus are clustered in two populations of surface structures on apoptotic keratinocytes. J Exp Med 1994; 179: 1317-1330.

117. Casciola-Rosen L, Rosen A, Petri M, Schlissel M. Surface blebs on apoptotic cells are sites of enhanced procoagulant activity: implications for coagulation events and antigenic spread in systemic lupus erythematosus. Proc Natl Acad Sci USA 1996; 93: 1624-1629.

118. Bellone M, lezzi G, Rovere P, Galati G, Ronchetti A, Protti MP et al. Processing of engulfed apoptotic bodies yields T cell epitopes. J Immunol 1997; 159: 5391-5399.

119. Albert ML, Pearce SF, Francisco LM, Sauter B, Roy P, Silverstein RL et al. Immature dendritic cells phagocytose apoptotic cells via alphavbeta5 and CD36, and cross-present antigens to cytotoxic T lymphocytes. J Exp Med 1998; 188: 1359-1368.

120. Pengand $\mathrm{Y}$, Elkon KB. Autoimmunity in MFG-E8-deficient mice is associated with altered trafficking and enhanced cross-presentation of apoptotic cell antigens. J Clin Invest 2011; 121: 2221-2241.

121. Bondanza A, Zimmermann VS, Dell'Antonio G, Cin ED, Balestrieri G, Tincani A et al. Requirement of dying cells and environmental adjuvants for the induction of autoimmunity. Arthritis Rheum 2004; 50: 1549-1560.

122. Ronchetti A, Rovere P, lezzi G, Galati G, Heltai S, Protti MP et al. Immunogenicity of apoptotic cells in vivo: role of antigen load, antigen-presenting cells, and cytokines. J Immunol 1999; 163: 130-136.

123. Rovere P, Manfredi AA, Vallinoto C, Zimmermann VS, Fascio U, Balestrieri G et al. Dendritic cells preferentially internalize apoptotic cells opsonized by anti-beta2-glycoprotein I antibodies. J Autoimmun 1998; 11: 403-411.

124. Rovere $\mathrm{P}$, Vallinoto $\mathrm{C}$, Bondanza A, Crosti MC, Rescigno M, Ricciardi-Castagnoli $\mathrm{P}$ et al. Bystander apoptosis triggers dendritic cell maturation and antigen-presenting function. J Immunol 1998; 161: 4467-4471.

125. Casares N, Pequignot MO, Tesniere A, Ghiringhelli F, Roux S, Chaput N et al. Caspasedependent immunogenicity of doxorubicin-induced tumor cell death. J Exp Med 2005; 202: 1691-1701.

126. Green DR, Ferguson T, Zitvogel L, Kroemer G. Immunogenic and tolerogenic cell death. Nat Rev Immunol 2009; 9: 353-363.

127. Kepp O, Senovilla L, Vitale I, Vacchelli E, Adjemian S, Agostinis P et al. Consensus guidelines for the detection of immunogenic cell death. Oncoimmunology 2014; 3: e955691.

128. Zong M, Bruton JD, Grundtman $\mathrm{C}$, Yang $\mathrm{H}$, Li JH, Alexanderson $\mathrm{H}$ et al. TLR4 as receptor for HMGB1 induced muscle dysfunction in myositis. Ann Rheum Dis 2013; 72 : 1390-1399.

129. Cappelletti C, Galbardi B, Kapetis D, Vattemi G, Guglielmi V, Tonin P et al. Autophagy, inflammation and innate immunity in inflammatory myopathies. PLoS One 2014; 9: e111490.

130. Nagaraju K, Casciola-Rosen L, Lundberg I, Rawat R, Cutting S, Thapliyal R et al. Activation of the endoplasmic reticulum stress response in autoimmune myositis: potential role in muscle fiber damage and dysfunction. Arthritis Rheum 2005; 52: 1824-1835.

131. Rayavarapu S, Coley W, Van der Meulen JH, Cakir E, Tappeta K, Kinder TB et al. Activation of the ubiquitin proteasome pathway in a mouse model of inflammatory myopathy: a potential therapeutic target. Arthritis Rheum 2013; 65: 3248-3258.

132. Sciorati C, Monno A, Ascherman DP, Seletti E, Manfredi AA, Rovere-Querini P. Required role of apoptotic myogenic precursors and Toll-like receptor stimulation for the establishment of autoimmune myositis in experimental murine models. Arthritis Rheumatol 2015; 67: 809-822.

133. Tournadreand A, Miossec $P$. A critical role for immature muscle precursors in myositis. Nat Rev Rheumatol 2013; 9: 438-442. 
134. Pereira BP, Tan BL, Han HC, Zou Y, Aung KZ, Leong DT. Intramuscular nerve damage in lacerated skeletal muscles may direct the inflammatory cytokine response during recovery. J Cell Biochem 2012; 113: 2330-2345.

135. Kaariainen M, Kaariainen J, Jarvinen TL, Sievanen H, Kalimo H, Jarvinen M. Correlation between biomechanical and structural changes during the regeneration of skeletal muscle after laceration injury. J Orthop Res 1998; 16: 197-206.

136. Dobek GL, Fulkerson ND, Nicholas J, Schneider BS. Mouse model of muscle crush injury of the legs. Comp Med 2013; 63: 227-232.

137. Ghalyand A, Marsh DR. Aging-associated oxidative stress modulates the acute inflammatory response in skeletal muscle after contusion injury. Exp Gerontol 2010; 45 381-388.

138. Winkler T, von Roth P, Matziolis G, Schumann MR, Hahn S, Strube P et al. Time course of skeletal muscle regeneration after severe trauma. Acta Orthop 2011; 82: 102-111.

139. Ambrosio F, Ferrari RJ, Distefano G, Plassmeyer JM, Carvell GE, Deasy BM et al. The synergistic effect of treadmill running on stem-cell transplantation to heal injured skeletal muscle. Tissue Eng Part A 2010; 16: 839-849.

140. Stauber WT. Factors involved in strain-induced injury in skeletal muscles and outcomes of prolonged exposures. J Electromyogr Kinesiol 2004; 14: 61-70.

141. Banks GB, Combs AC, Chamberlain JR, Chamberlain JS. Molecular and cellular adaptations to chronic myotendinous strain injury in $\mathrm{mdx}$ mice expressing a truncated dystrophin. Hum Mol Genet 2008; 17: 3975-3986.

142. Pratt SJ, Lawlor MW, Shah SB, Lovering RM. An in vivo rodent model of contractioninduced injury in the quadriceps muscle. Injury 2012; 43: 788-793.

143. de Paiva Carvalho RL, Leal-Junior EC, Petrellis MC, Marcos RL, de Carvalho MH De Nucci G et al. Effects of low-level laser therapy (LLLT) and diclofenac (topical and intramuscular) as single and combined therapy in experimental model of controlled muscle strain in rats. Photochem Photobiol 2013; 89: 508-512.
144. Warren GL, Summan M, Gao X, Chapman R, Hulderman T, Simeonova PP. Mechanisms of skeletal muscle injury and repair revealed by gene expression studies in mouse models. J Physiol 2007; 582: 825-841.

145. Szelenyiand ER, Urso ML. Time-course analysis of injured skeletal muscle suggests a critical involvement of ERK $1 / 2$ signaling in the acute inflammatory response. Muscle Nerve 2012; 45: 552-561.

146. Vignaud A, Hourde C, Medja F, Agbulut O, Butler-Browne G, Ferry A. Impaired skeletal muscle repair after ischemia-reperfusion injury in mice. J Biomed Biotechnol 2010; 2010: 724914.

147. Loenneke JP, Thiebaud RS, Abe T. Does blood flow restriction result in skeletal muscle damage? A critical review of available evidence. Scand J Med Sci Sports 2014; 24: e415-e422.

148. van der Meer SF, Jaspers RT, Jones DA, Degens $\mathrm{H}$. Time-course of changes in the myonuclear domain during denervation in young-adult and old rat gastrocnemius muscle. Muscle Nerve 2011; 43: 212-222.

149. Hikida RS, Van Nostran S, Murray JD, Staron RS, Gordon SE, Kraemer WJ. Myonuclear loss in atrophied soleus muscle fibers. Anat Rec 1997; 247: 350-354.

150. Dupont-Versteegden EE, Murphy RJ, Houle JD, Gurley CM, Peterson CA. Activated satellite cells fail to restore myonuclear number in spinal cord transected and exercised rats. Am J Physiol 1999; 277: C589-C597.

151. Harris JB. Myotoxic phospholipases A2 and the regeneration of skeletal muscles. Toxicon 2003; 42: 933-945.

152. Kawai H, Nishino H, Kusaka K, Naruo T, Tamaki Y, Iwasa M. Experimental glycerol myopathy: a histological study. Acta Neuropathol 1990; 80: 192-197.

153. Pisani DF, Bottema CD, Butori $C$, Dani $C$, Dechesne $C A$. Mouse model of skeletal muscle adiposity: a glycerol treatment approach. Biochem Biophys Res Commun 2010; 396: 767-773. 